\title{
Farmers' Perception and Adaption to Land Use Change and Climate Variability in Fina Reserve, Mali.
}

\author{
Karamoko Sanogo ${ }^{1,2 *}$, Souleymane Sanogo ${ }^{2}$, Abdramane $\mathrm{Ba}^{2}$ \\ ${ }^{I}$ WASCAL Coordinating Secretariat, Federal University of Technology, PMB 65, Bosso Campus, Minna, Niger State, Nigeria \\ ${ }^{2}$ Laboratoire d'Optique, de Spectroscopie et des Sciences de l'atmosphère (LOSSA), Université des Sciences de Techniques et de Technologie \\ de Bamako, MALI. BPE 3206
}

\begin{tabular}{l}
\hline A R T I C L E I N F O \\
Article history: \\
Received 16 September 2015 \\
Accepted 01 April 2016 \\
Available online, ISSN: 2148-127X \\
\hline
\end{tabular}

Keywords:

Adaptation

Climate change

Farmers perception

Fina reserve

Mali.

*Corresponding Author:

E-mail: karasanogo@gmail.com

\begin{abstract}
A B S T R A C T
Like the whole sub-Sahara Africa, rainfall in Fina reserve is subject of strong inter-annual variability. This paper assesses farmers' perception on land use utilised in the Fina biosphere reserve and their adaptation measures to climate variability. The statistical methods (descriptive and inferential analysis) are used in this study to determine farmers' perceptions and the adaptation measures in the Fina reserve. Results reveal that $75.5 \%$ of the farmers noticed an increase in temperature and decrease in rainfall ignoring the recent recovery observed in the annual rainfall. The length of rainy season is considered to be shorter according to $77.6 \%$ of farmers involved to the investigation. However, all the farmers underlined frequent and longer dry spell. Bush fire is considered by $10.2 \%$ of farmers as the major factor affecting the natural resources of the reserve and only about $10 \%$ of farmers accorded much importance to agricultural land as contributor to reserve degradation. Most of the farmers are limited by lack of manpower and not by the reserve rule to increase their farmlands. The major adaptation measures are the methods of shifting cultivation and improving seed which are practiced by $51 \%$ and $87.8 \%$ of farmers, respectively. New adaptation strategies such as adoption of planting pits and stone-bunds for water retention need to be practiced by farmers.
\end{abstract}

\section{Introduction}

The agricultural sector in Mali is led by small scale rural farmers, who depend on rainfall for crop production. Hence any change in rainfall events (droughts and floods) adversely affects household food security. Most of the sub-Sahara African population lives in miserable condition, and deeply reliant on rain-fed crop production which made Sub-Sahara Africa region the most vulnerable to climate change impacts. Adaptation measures to climate variability are therefore necessary for reducing its negative effects. In the context of climate change, adaptation strategies are not unique and farmer's responses will vary across the regions.

Changes in rainfall and temperature patterns have significant influence on socio-economic development (African Partnership Forum [APF], 2008). The sectors of economy are also impacted by climate change by the fact that its primary products are from the agriculture sector which is yet affected. Farmers' perceptions on rainfall and temperature variation differ according to the sub-region of Africa. While decreasing trend and amount of precipitation is reported for southern Africa (Nyanga, et al., 2011), a partial recovery is observed in precipitation of western Africa (Nicholson, 2005; Sanogo et al., 2015). Farmers perceived that the rainfall amount and temperature in Sub-Sahara Africa were undergoing a year to year variability (Gandure et al., 2012). Nevertheless, summer and winter are becoming hotter and colder, respectively in that sub-region (Gandure et al., 2012).

Farmers' perception and the trends of climate factors (Temperature and rainfall) are in agreement on warmer and drier conditions in the Southern African region (Nhemachena and Hassan, 2007). Perceptions are influenced by different set of demographic, socioeconomic, geophysical and biophysical characteristics of the respondents such as farm size, distance of household from forest margin (Guthiga, 2008). Thus, in order to address people interest in forest conservation, there is need for forest managers to pay attention to these factors. It was demonstrated that farming and hunting respectively through the cutting of tree fodder and the use of fire to 
clear areas are among the main socio-economic factors of vegetation cover degradation (Arouna, 2011). The mutual interactions between these socio-economic factors make difficult to find out the contribution of individual factor in the degradation of vegetation cover.

Developing adaptation measures for farmers starts firstly by the awareness that climate has changed and then identification the useful adaptations measures and the means of their implement (Maddison, 2006). Meteorological data could be used to determine the perception of climate change by famers; this was shown in several studies on farmers' perceptions of climate (Slegers, 2008; West et al., 2008; Mertz, et al., 2009).

In Mali, extensive agriculture land have being in increasing proportion as in most West African countries. This issue is one of the challenges of saving protected and national park area in Mali as the case of Fina Reserve (Direction Nationale de la Conservation de la Nature [DNCN] 2006). In 2011, the growth of agriculture encroachment was about $23 \%$ over 19 years (1.2\% a year) on the peripheral of Fina reserve and its extension toward the protected zones is observed (Diallo et al., 2011). Also a part of the reserve had been decommissioned in 1993 to satisfy the growing need for farmland and pasture riparian and transhumant populations. This decommissioning has affected a part of the core area (strictly protected area) of Fina Reserve which decreased from 136,000 hectares to 108,668 hectares (Diallo et al., 2011). Despite this, the area continues to experience very strong pressures from animal and human activities. Many small villages are located around Fina reserve resulting of strong anthropogenic pressure to the reserve. The impacts of these activities on the reserve reach an excessive level thereby, leading to reduction of natural resources (Diallo et al., 2011). Moreover, it was concluded that the anthropogenic effects on the vegetation have resulted in a large influx of transhumance (livestock) and cultured zone in a relationship with a population growth in the reserved area (Dembélé, 1996).

$\mathrm{Ba}$ et al., (2004) showed that favorable natural conditions in the Reserve have made in recent years, agricultural settlement area that welcomes more farmers and ranchers from the city of Kolokani and around the reserve. Such colonization of space is particularly noteworthy in sub-Saharan Africa, where rapid population growth and agricultural crisis encourage emigration to research favorable farmland. Excessive cutting of wood has already been revealed as an important factor in the regressive dynamics of woody in Fina reserve (Faye et al., 2008). The overexploitation of the land is considered as the main cause of degradation of vegetation cover and biodiversity loss (Bouko et al., 2007). This phenomenon is also observed in several West African regions (Ariori and Ozer, 2005 and Sawadogo et al., 2008). Moreover bush fires affect most vegetation types from fallow to woodlands, often making complex discrimination between vegetation classes. These same problems have been reported by other authors (Dembélé, 1996; N'Guessan et al., 2006).

In the context of climate change and growing population, the objectives of this research article are (1) to determine farmers' perceptions on climate change and land use/cover change; and (2) to identify adaptation strategies practiced by farmers' to cope with the impact of climate variability.

\section{Material and Methods}

\section{Study Area}

The Fina Reserve, located in the Sudanese ecological zone with 136,000 hectares (Nasi, 1994), is launch in western part of Mali, between $13^{\circ} 10^{\prime}-13^{\circ} 40^{\prime}$ north latitude and $9^{\circ} 30^{\prime}-9^{\circ} 50^{\prime}$ West longitude (Figure 1). The reserve of Fina is comprised of two components. A core area (strictly protected area) of 108,668 hectares strictly protected from any humane activities while some humane activities as agriculture and pastoral could be done in remain part of the reserve. There are two types of livestock farming, first one is settled livestock farming linked to agricultural farming and the second is the transhumant livestock farming related to a specific population.

Data

In this study, historical rainfall and air temperature from 1980 to 2014 and socio-economic data from interviews of households were used to show the climate variability in the Fina reserve and farmers' perception and adaptation strategies to change in climate and land use. Interviews were based on questionnaires which were designed to combine qualitative variables (unstructured) and quantitative measurable variables (structured) relevant to the objective of study. The language used for interviews and discussions was the Bambara which is predominating speak language in the locality. All the villages involved to socio-economic data collection are about 2 to $5 \mathrm{~km}$ to the protected core area of the reserve. Thus, forty-nine households were selected in four villages. Large ranges of data were collected in the survey. However, farmers' perceptions on climate change, land use change, adaptations and barriers to adaptation were the major section of the survey.

The statistics in Table 1 show that there is a huge percentage of men than women, with $91.8 \%$ against $8.2 \%$, respectively involved in the survey. The households were divided according to their age and $53.1 \%$ of the respondents were more than 50 years old. Furthermore, large proportion of the respondents is not educated only $8.2 \%$ of the entire respondents are educated and most of the farmers educated were less than 30 years old.

\section{Analysis}

Linear regression statistic is used to determine the fluctuation and trend from 1980 to 2014 of the total annual rainfall and the annual mean temperature. The significance of the trend is assessed by using MannKendall trend test statistics. This statistical test is robust since it is not affected by outliers. Farmer perceptions were determined by using descriptive statistics for the characterisation of climate change notion, land use 
change, adaptations and barriers to adaptation followed by farmers. Data was analysed by SPSS software to generate percentage and frequency charts and tables. The frequency was used for each question and computed in percentage to determine farmers' perceptions. The linear correlation was used in this study to the relationship between age of household and the perception on land use and climate change.

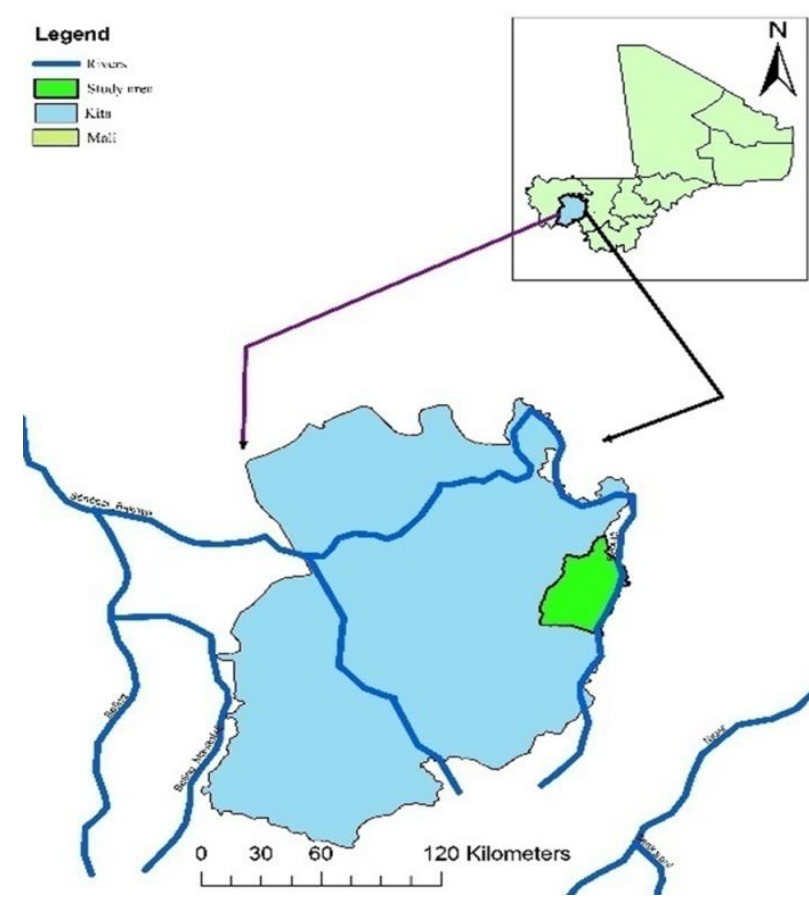

Figure 1 Map of Fina reserve and its localisation in the map of Mali.

Table 1 Statistics according to gender, age and education level of farmers involved in the data collection survey

\begin{tabular}{l|lc}
\hline & & Respondents (\%) \\
\hline \multirow{2}{*}{ Gender } & Men & 91.8 \\
& Women & 8.2 \\
\hline \multirow{3}{*}{ Age } & $<30$ years & 8.3 \\
& $>30$ \& $<50$ years & 38.6 \\
& $>50$ years & 53.1 \\
\hline \multirow{2}{*}{ Education } & schooled & 8.2 \\
& Not schooled & 91.8 \\
\hline
\end{tabular}

\section{Results and Discussion}

Climate Variability and its Perceptions by Farmers

Figure 2 highlights the inter-annual variability of rainfall and air temperature in the study area. The period starting by late 1990s has known more abundant rainfall confirming the finding of some previous studies revealing that the Sahel rainfall has recovered from the droughts conditions of the 1980s (Nicholson, 2005; Sanogo et al., 2015). The linear regression analysis (Figure 2.a) shows an increasing trend of the annual rainfall with an increasing rate of about $5.58 \mathrm{~mm}$ per year exceeding $95 \%$ level of significance according to Mann-Kendall statistical test. The air temperature shows an increasing trend with a rate of $0.04^{\circ} \mathrm{C}$ per year at $99 \%$ level of significance (Figure 2.b). Indeed, the analysis indicated that there is a large fluctuation in the annual amount of precipitation from year to year with less amount of rainfall from 1980 to mid-1990s coinciding to the period of severe drought in sub-Sahara Africa.

In order to know how farmers perceived the effects of climate change, they were asked about their knowledge on changes occurred to weather over the years. Precipitation is the climate factor which affects the most farmers' activities and yields. Thus, $72.5 \%$ of farmers found that the annual accumulated rainfall is decreasing and $75.5 \%$ of farmers denote an increase temperature (Table 2). The results of the survey further reveal that only $16.3 \%$ of farmers have perceived and understood the phenomena of the recent rainfall recovery characterised by the occurrence of more intense rains and flooding events (Nicholson, 2005; Sanogo et al., 2015). However, $91.8 \%$ of farmers have perceived the late rainfall onset which has been established by statistical analysis in Sanogo et al. (2015). The length of rainy season is considered to be shorter according to $77.6 \%$ of farmers involved to the investigation. However, all the farmers underlined the frequent and longer dry spell observed over the past three decades. Obviously, perception of more than $75 \%$ of local farmers is not in line with rainfall trend observed during the last decades over the reserve.

The temperature, which is one of climate change indicators, is perceived differently by local famers in Fina Reserve. Table 2 indicated that $75.5 \%$ of the farmers noticed an increasing temperature while $18.4 \%$ believe that the temperature had decrease over time. From this result, a significant number of farmers are confident and aware about the increase observed in air temperature (Table 2). As result of this warning condition, evapotranspiration will increase which induces stress to plants by suffering because of excessive losing of water contain. Farmers understand the impacts of climate change by its direct effects such as severe drought, lack of rainfall, flooding events and high temperature. Thus, only about 6 to $10 \%$ of farmers know that increasing temperature and flooding events are direct effects of climate change (Table 3). Moreover, lack of rains as severe drought and longer dry spell has been considered as major effects of climate change by $30.8 \%$ of farmers.

\section{Farmers' Perception on Land Use and Land Cover Change \\ Historical land use and farmers' perception on land} cover change: In the reserve of Fina, farmers used to get their farms through two ways: either they inherit existing farm from their parents or they clear forest to get new farmland. The statistical analysis showed that over the last three decades, $59.2 \%$ of farmers have cleared the forest to get their farmland and $40.8 \%$ of farmers have got their farms from converting fallow land. The survey results indicate that farmlands from fallow are been cultivating for more than 50 years while forest cleared farmlands are been cultivating less than 10 years. Few farmers (about $10 \%$ ) have practiced cultivation with changing crop 
variety (using sorghum, millet, cotton and groundnut) in their farms. However, the majority of farmers have cultivated only sorghum and millet continuous more than 30 years in most of the farms, this cultivating practice was contributing to the loss of soil nutrient.

The main activities susceptible to increase the degradation rate of the natural resource in Fina reserve are farming activity, cutting trees for firewood and charcoal production, bush burning etc. Previous finding of Faye et al. (2008) revealed that excessive cutting of wood is an important factor in the regressive dynamics of woody in
Fina reserve. Results from the interview reveal that only $10.2 \%$ of farmers recognized that there had been change in land cover in Fina reserve. Bush fire is considered by $10.2 \%$ of farmers as the major factor of land cover change and affecting the natural resources of the reserve. These results are arguable since N'Guessan et al. (2006) reported that bush fires affect most of vegetation types as fallow and woodlands, often making complex discrimination between vegetation classes. About $10 \%$ of farmers accorded much importance to agricultural land as contributor to reserve degradation.
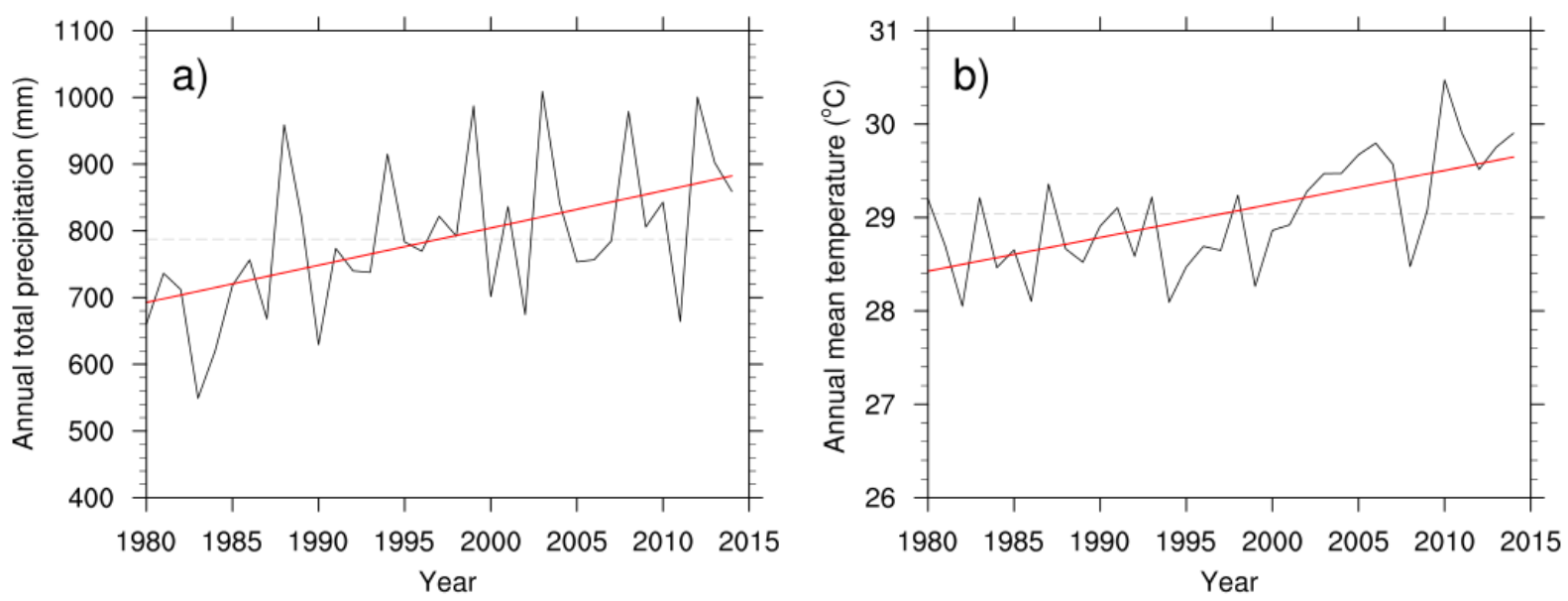

Figure 2 Inter-annual variability of rainfall (a) and temperature (b) in the reserve of Fina from 1980-2014. The red and grey lines indicate the trend line and the long term mean value, respectively

Table 2 Farmer's perception on the change direction of potential climate change indicators (as a Percentage of respondents)

\begin{tabular}{l|ccc}
\hline \multirow{2}{*}{ Parameters } & \multicolumn{3}{c}{ Percentage of respondents } \\
\cline { 2 - 4 } & Increase (\%) & Decrease (\%) & No change $(\%)$ \\
\hline Annual Rainfall & 21.50 & 72.50 & 6.00 \\
Rainfall intensity & 16.30 & 77.60 & 6.10 \\
Air temperature & 75.50 & 18.40 & 4.10 \\
Length of rainy season & 6.10 & 91.80 & 6.10 \\
\hline
\end{tabular}

Farmers expectation and limitation to increase their farms sizes: Except in the protected core of the reserve, farmers are not under any rule of natural reserve which could limit farming activities. This evidence is shown in Figure 3 where $53.1 \%$ of farmers are limited by lack of manpower but not by reserve rule to increase their farms size. Also, $24.5 \%$ of respondents do not have any limitation for changing their farms size. The result further indicates that land tenancy is considered as second limiting factor of farmers to increase their farms size. About $8 \%$ of farmers did not increase their farms size because of the precarious farming condition as result of climate variability.

The adaptation measures proposed as solution to agricultural land degradation are weakly practiced; as result, farmers are more and more incited to make new farmlands by clearing the forest. It was evaluated in this study that $93.9 \%$ of farmers need strategies for management of their farm soil nutrient. The result showed a high percentage of forest clearing for the purpose of increasing the farm size. About $91.8 \%$ of farmers have increased their farms size (including fallow) over the last two decades and they intend to increase the size in the future. Figure 4 showed that $44 \%, 16.3 \%$ and $16 \%$ of total householders have intention to increase their farmlands size by 1,2 and 4 hectares per year respectively. The survey further highlights that all householders wish to increase their farms size; this could likely contribute to increase the degradation of the reserve natural resource. This remark is consistent with this finding of Bouko et al. (2007) revealing that the overexploitation of the land is considered as the main cause of degradation of vegetation cover and biodiversity loss. 
Table 3 Farmers understanding on the most indicating phenomenon of climate change

\begin{tabular}{l|c}
\hline & Percentage of respondents \\
\hline Flooding events & 6.0 \\
Heat wave & 6.2 \\
Drought \& dry spell & 87.8 \\
\hline
\end{tabular}

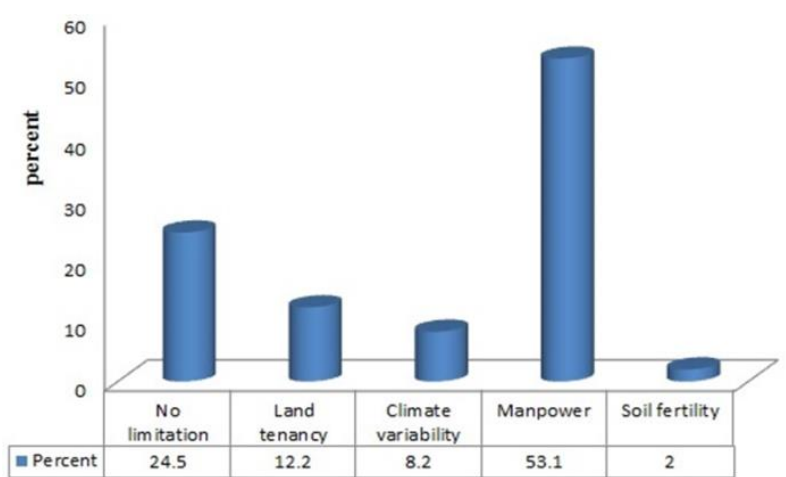

Figure 3 Statistic of farmers' limitation and associated reason to increase the farms size.

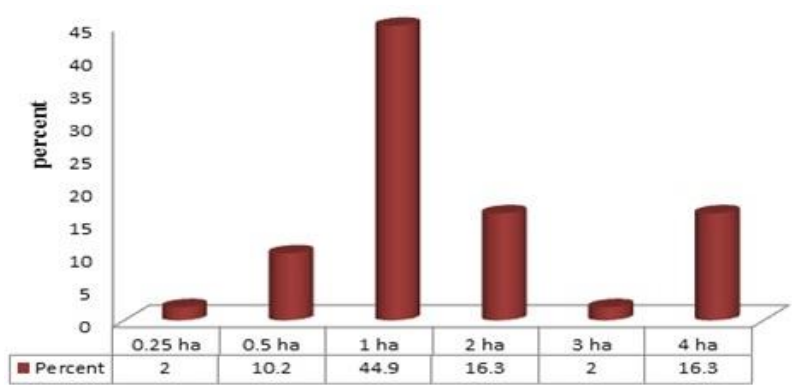

Figure 4 Percentage of respondents indicating farmers' expectation to increase their farmlands size.
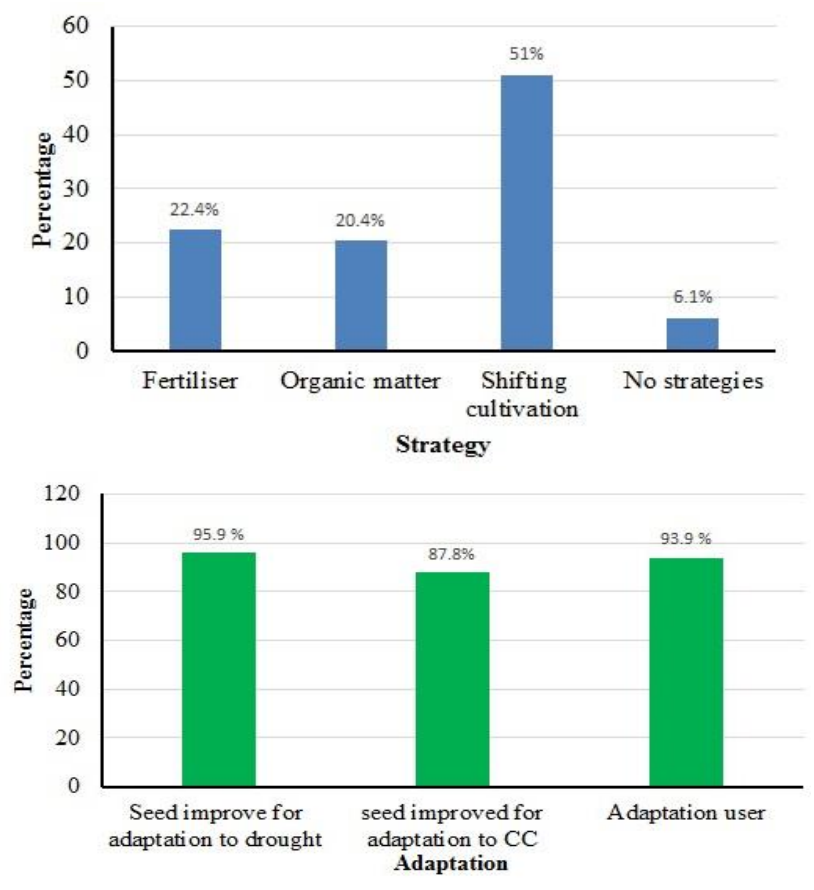

Figure 5 Adaptation strategies (as a percentage of respondents)of farmers in Fina reserve to cope with climate variability and farmland degradation.

\section{Coping and Adapting to Climate Change and} Variability

Adaptation measures were used by most of households involved in the present survey. Figure 5.a shows that shifting cultivation is the most adaptation measure used in Fina reserve by $51 \%$ of farmers. However, $22.4 \%$ and $20.4 \%$ of farmers used chemical fertilizer and organic composite, respectively, to cope with the soil poverty. The organic composite used are from animals waste while the chemical fertilizer is buy from market. In Fina reserve, $81.6 \%$ of households possess animals, but only $20.4 \%$ of farmers used animals waste as soil fertiliser. This results indicate that much number of farmers that have animals do not know about the importance of animals waste in adaptation strategy to increase soil nutrient.

The cultivation of short cycle crops allows farmers to take advantage of the short maturing time of crops which strengthen their resilience to the likely effects from unpredictable of rainfall fluctuation and the associated drier conditions. This adaptation strategy is practiced in by $95.9 \%$ of farmers of Fina reserve (Figure $5 . \mathrm{a} / \mathrm{b}$ ) to increase their chances of harvesting yield during the drier and shorter rainy seasons. This adaptive strategy to climate variability is widely used in sub-sahara as the case of Kenyan farmers from Makueni (Speranza, 2010) and Namibian farmers (Newsham and Thomas 2009, 2011) who cultivated early maturing crops to cope with drier conditions. Moreover, $87.8 \%$ of farmers change their seed and use the improved seed. Farmers from Fina reserve are facing with unpredictable effects of climate variability; thus they adopt different responses to cope with the conditions. Much of their responses are triggered by past or current events (reactive response). However, farmers' responses should be anticipatory and should be based on assessment of conditions in the future (e.g., rainfall occurrences). Some adaptation measures may already be practiced before extreme climate events (e.g. droughts). Such adaptive measures at traditional farming level have been discussed as the most used due to uncertainties faced by farmers (Darnhofer et al., 2010).

\section{Conclusion}

The agricultural sector of Mali is largely led by small scale rural farmers and it is seriously affected by rainfall fluctuation. Fina reserve' farmers, in majority, are aware that climate has changed. They understand the impacts of climate change by its direct effects such as severe drought, lack of rainfall, flooding events and high temperature. Lack of rains as severe drought and longer dry spell has been considered as major effects of climate change by $30.8 \%$ of farmers. The severe droughts were the most known climate impact by farmers and farmers are more vulnerable to the effects of climate change because of the lack information. The majority of farmers of Fina reserve perceive the increase temperature but ignore the recent recovery observed in the annual rainfall characterised by the occurrence of more intense rains and flooding events. 
Farmers are limited by lack of manpower but not by reserve rule to increase their farms size. Consequently, the totality of householders wishes to increase their farms size in future, which could likely contribute to increase the degradation rate of the reserve natural resource.

To cope with climate variability and loss of soil nutrients, the main adaptation strategies used by farmers in Fina reserve consist of:

- The cultivation of short cycle crops as response of the shorter duration of the rainy season. This strategy uses the variety of crops that are tolerant to drought and high temperature,

- Shifting cultivation which allows the land to be fertile at less cost. When the soil shows signs of exhaustion or overrunning by weeds, the cultivator moves on to another plot allowing soil to revert to their natural vegetation,

- Utilisation of chemical fertilizer and organic composite which allows farmers to continuously achieve high yields on the same land for many years. This practice eliminates the need for clearing new area of forest,

In addition, new adaptation strategies need to be practiced by farmers like structures of establishing water harvesting such as the zais and stonebunds for water retention in the farm. The zai or planting pits combined with organic manure considerably improve the soil's chemical and physical properties enabling better crop establishment. These structures reduce the risk for crop failure and increase yields.

\section{Acknowledgement}

The fieldwork was funded by the German Federal Ministry of Education and Research (BMBF) through the West African Science Service Centre on Climate Change and Adapted Land Use (WASCAL). The authors gratefully acknowledge farmers communities from Fina reserve for their time, kindness and cooperation throughout data collection. We are grateful to the support of the International Science Programme (ISP) to the Laboratory of Optics, Spectroscopy and Science of atmosphere (LOSSA) at the 'Faculté des Sciences et Techniques de Bamako' which has provided work environment, data and facilities. Finally, we wish to thank the anonymous reviewers whose comments helped to improve the article.

\section{References}

APF. 2008. Acting on Climate Change for Sustainable Development in Africa or Seventh African Development Forum.

Ariori SL, Ozer P. 2005. Évolution des ressources forestières en Afrique de l'Ouest soudano-sahélienne au cours des 50 dernières années. Geo-Eco-Trop 29: 61-68.

Arouna M. 2011. Comparative Analysis of Local Populations' Perceptions of Socio-economic Determinants of Vegetation degradation in Sudano-Guinean area in Benin. Choice of Adaptation Methods and Perceptions of Climate Change in the Nile Basin of Ethiopia, IFPRI Discussion Paper 00798: International Food Policy Research Institute.
Ba M, Touré A, Reenberg A. 2004. Mapping land use dynamics in Senegal. Case studies from Kaffrine Departments. Sahel-Sudan Environmental Research Initiative (SEREIN) Working Paper 45: 1-33.

Bouko BS, Sinsin B, Soulé GB. 2007. Effets de la dynamique d'occupation du sol sur la structure et la diversité floristique des forêts claires et savanes au Bénin. Tropi. Cultura 25: 221-227.

Darnhofer I, Bellon S, Dedieu B, Milestad R. 2010. Adaptiveness to enhance the Sustainability of farming systems. A review. Agron. Sustain. Dev. 30:545-555.

Dembélé F. 1996. Influence du feu et du pâturage sur la végétation et la biodiversité dans les jachères en zone soudanienne-nord du Mali. Cas des jeunes jachères du terroir de Missira (cercle de Kolokani). Thèse de doctorat, université de Droit, d'Economie et des Sciences, Aix-Marseille III.

Diallo H, Bamba I, Sabas BYS, Visser M, Ballo A, Mama A, Bogaert J. 2011. Effets combinées du climat et des pressions anthropiques sur la dynamique évolutive de la végétation d'une zone protégée du Mali (Réserve de Fina, Boucle du Baoulé). Sécheresse 22: 97-107.

DNCN. 2006. Communication du ministère de l'Environnement au forum national de Ségou sur l'état de l'environnement au Mali. Bulletin d'Information Réseau "Réussir la Décentralisation', au Mali : 6-9 Direction nationale de la conservation de la nature.

Faye E, Diatta M, Samba ANS, Lejoly J. 2008. Usages et dynamique de la flore ligneuse dans le terroir villageois de Latmingué (Sénégal). Journal des Sciences et Technologies 7: 43-58.

Gandure S, Walker S, Botha JJ. 2012. Farmers' perceptions of adaptation to climate change and water in a South African rural community. Environment Development. Retrieved from. doi.org/10.1016/j.endev. 11:004.

Guthiga P M. 2008. Understanding local community perceptions of existing forest management approaches of a Kenyan rainforest. International Journal of Social Forestry 1(2): 145-167.

Maddison D. 2006. The perception of and adaptation to climate change in Africa. CEEPA Discussion Paper No.10. Centre for Environmental Economics and Policy in Africa, University of Pretoria, South Africa.

Mertz O, Mbow C, Reenberg A, Diouf A. 2009. Farmer's Perception of Climate Change and Agricultural Adaptation Strategies in Rural Sahel. Environmental Management 43:804-816, doi: 10.1007/s00267-008-9197-0.

N'Guessan E, Dibi H, N'Da, Bellan MF, Blasco F. 2006. Pression anthropique sur une réserve forestière en Côte d'ivoire : Apport de la télédétection. Télédétection 5: 307-323.

Nasi R. 1994. La Végétation du centre régional d'endémisme soudanien au Mali. Etude de la forêt des Monts Mandingues et essai de synthèse. Thèse de doctorat, université de Paris-Sud XI.

Newsham A, Thomas D. 2009. Agricultural Adaptation, Local Knowledge and Livelihoods Diversification in North-Central Namibia; Tyndall working Paper 140; Tyndall Centre for Climate Change Research: Norwich, UK, 2009.

Newsham AJ, Thomas DSG. 2011. Knowing, farming and climate change adaptation in North-Central Namibia. Global Environ. Change 21: 761-770.

Nhemachena C, Hassan R. 2007. Micro-Level Analysis of Farmers' Adaptation to Climate Change in Southern Africa. IFPRI Discussion Paper 00714 August 2007

Nicholson S. 2005. On the question of the "recovery" of the rains in the West African Sahel. Journal of Arid Environments, vol. 63, no. 3, pp. 615-641.

Nyanga PH, Johnsen FH, Aune JB. 2011. Smallholder Farmers' Perceptions of Climate Change and Conservation Agriculture: Evidence from Zambia. Journal of Sustainable Development. doi:10.5539/jsd.v4n4p73.

Sanogo S, Fink A, Omotosho JB, Ba A, Redl R, Ermert,V. 2015. Spatio-temporal characteristics of the recent rainfall recovery in West Africa. International Journal of Climatology, 35: 45894605 (2015). DOI: 10.1002/joc.4309. 
Sawadogo H, Zombre PN, Bock L, Lacroix D. 2008. Évolution de l'occupation du sol de Ziga dans le Yatenga (Burkina Faso) à partir de photos aériennes. Revue de Télédétection 8: 59-73.

Slegers MFW. 2008. "If only it could rain": Farmers' perceptions of rainfall and drought in semi-arid central Tanzania. Journal of Arid Environments 72: 2106-2123. doi:10.1016/j.jaridenv.2008.06.011.
Speranza CI. 2010. Drought coping and adaptation strategies: Understanding adaptations to climate change in agro-pastoral livestock production in Makueni district, Kenya. Eur. J. Dev. Res. 22: 623-642.

West CT, Roncoli C, Ouattar F. 2008. Local perceptions and regional climate trends on central plateau of Burkina Faso. Land degradation and Development, 19: 289-304. 